\title{
Pengaruh Pembagian Kerja Terhadap Kepuasan Kerja: Studi Kasus pada Pegawai di Perum DAMRI Bandung
}

\author{
Received: \\ 29 Juli 2021 \\ Revision \\ received: \\ 30 Juli 2021 \\ Accepted: \\ 4 Agustus 2021 \\ Pratiwi* dan Ermina Tiorida \\ Jurusan Administrasi Niaga, Politeknik Negeri Bandung, Indonesia

\begin{abstract}
:
The background of this research is based on the phenomenon where the placement of employees hasn't been adjusted to the skills and educational background. In addition, the unequal division of labor causes productivity to decrease, resulting in an attitude of dissatisfaction shown by employees. This study aims to analyze the effect of the division of labor on employee job satisfaction. This study uses a quantitative approach to explanatory survey methods with a sample of 101 respondents who are employees of the Perum DAMRI Bandung office. Data processing was carried out using IBM SPSS Statistics 24. In this study, it was found that the division of labor was in the sufficient category and the job satisfaction was in a good category. The results of this study there's a positive and significant influence on the division of labor on job satisfaction of Perum DAMRI Bandung employees with an influence value of $24.4 \%$.
\end{abstract}

Keywords: division of labor, human resources, job satisfaction

\begin{abstract}
Abstrak:
Latar belakang dari penelitian ini berdasarkan pada fenomena di mana penempatan pegawai belum disesuaikan dengan keterampilan serta latar belakang pendidikan. Selain itu, pembagian kerja yang belum merata menyebabkan produktivitas menjadi menurun sehingga timbul sikap ketidakpuasan yang ditunjukkan oleh para pegawai. Penelitian ini bertujuan untuk menganalisis efek dari pembagian kerja terhadap kepuasan kerja pegawai. Penelitian ini menggunakan pendekatan kuantitatif metode survei eksplanatori dengan jumlah sampel 101 responden yang merupakan pegawai kantor Perum DAMRI Bandung. Pengolahan data dilakukan menggunakan bantuan IBM SPSS Statistics 24. Dalam penelitian ini, ditemukan bahwa variabel pembagian kerja berada dalam kategori cukup dan untuk variabel kepuasan kerja berada dalam kategori baik. Hasil dari penelitian ini yaitu adanya pengaruh positif dan signifikan pembagian kerja terhadap kepuasan kerja pegawai Perum DAMRI Bandung dengan nilai pengaruh sebesar $24,4 \%$.
\end{abstract}

Kata kunci: kepuasan kerja, pembagian kerja, sumber daya manusia

\section{Pendahuluan}

Perum DAMRI Bandung merupakan salah satu badan usaha milik negara yang kegiatannya bergerak di bidang jasa transportasi. Perum DAMRI berkomitmen untuk terus mewujudkan layanan prima bagi pelanggan yang tersebar di seluruh provinsi Indonesia (DAMRI, 2019). Dalam mewujudkan pelayanan yang prima Perum DAMRI Bandung memiliki tujuan di mana semua pegawai dapat melakakukan pekerjaannya dengan baik. Maka dari itu, agar pegawai dapat melakukan pekerjaannya dengan optimal, pihak manajemen perlu melakukan pembagian kerja dengan baik. Namun, hasil observasi menunjukkan masih adanya masalah terkait pembagian kerja yang belum merata di Perum DAMRI Bandung bahkan pegawai dibebani tugas yang bukan bagiannya. Hal ini tentu saja bertentangan dengan definisi dari 
pembagian kerja menurut (Hastyorini, 2019) yaitu perincian tugas pekerjaan supaya tiap individu dalam organisasi bisa bertanggung jawab untuk melaksanakan sekumpulan kegiatan terbatas.

Untuk membuktikannya dilakukan pra-penelitan dengan sampel acak kepada 30 orang pegawai pada 5 divisi dan hasilnya 73,3\% merasa bahwa pembagian kerja di antara pegawai belum merata. 46,7\% menyatakan sering mengerjakan tugas di luar pekerjaan utamanya dan 43,3\% menyatakan kadang mengerjakan tugas di luar pekerjaan utamanya. Hal ini mengindikasikan bahwa deksripsi pekerjaan yang telah dilakukan masih belum terdeksripsi dengan jelas, tugas tambahan pun seringkali tidak dicatat dalam deksripsi pekerjaan. Ada juga beberapa pegawai yang memiliki jenis pekerjaan yang beragam sehingga salah satu tugasnya tidak dapat terlaksana dengan baik karena masih harus menyelesaikan tugas rutin lain miliknya. Hal ini mengindikasikan bahwa analisisis dari pembagian beban kerja belum terlaksana dengan baik. Adapun $70 \%$ pegawai merasa bahwa ilmu pengetahuan, pengalaman, dan keterampilan belum menunjang beban kerja mereka dan masih harus belajar lagi.

Hal tersebut tentunya akan berdampak pada terhambatnya pencapaian tujuan perusahaan dan tentunya akan berdampak pada ketidakpuasan kerja yang dialami oleh pegawai. Output yang timbul dari ketidakpuasan kerja dapat menyebabkan produktivitas pegawai menurun (Afandi, 2016). Produktivitas pegawai dapat dilihat dari kualitas kerja, kuantitas kerja, serta ketepatan waktu. Pada prapenelitan dengan sampel acak kepada 30 orang pegawai pada 5 divisi dan hasilnya pada kualitas kerja $73,3 \%$ menyatakan kadang mengalami revisi secara berulang dan $23,3 \%$ menyatakan bahwa mereka sering mengalami revisi secara berulang hal ini menandakan bahwa kualitas pekerjaan mereka masih belum sesuai dengan yang diharapkan atau ditentukan oleh perusahaan. Pada kuantitas pekerjaan, $63,3 \%$ menyatakan kadang memenuhi target capaian yang ditetapkan oleh perusahaan. Hasil pekerjaan yang tidak mencapai target tentunya akan berdampak pada kinerja perusahaan. Pada ketepatan waktu, 53,3\% menyatakan kadang melewati batas waktu yang ditentukan dan 36,7\% menyatakan sering melewati batas waktu yang telah ditentukan. Ini mengindikasikan bahwa beberapa pegawai belum memaksimalkan waktu yang tersedia untuk menyelesaikan tugasnya.

Selain memiliki pengaruh pada produktivitas, kepuasan kerja juga dapat dilihat dari sikap atau ciriciri yang dimiliki oleh pegawai. Dari hasil observasi yang dilakukan: 1) Terdapat beberapa pegawai yang mengeluh dengan tugas yang dibebankan kepadanya. 2) Beberapa pegawai sering datang terlambat dan pulang lebih awal 3) Ada pegawai yang kurang betah berada di tempat kerja, sehingga saat jam kerja orang tersebut pergi ke luar dan kembali saat jam kerja akan selesai. Fenomena tersebut tentu saja bertentangan dengan ciri-ciri pegawai yang merasa puas seperti yang diutarakan oleh (Chaerudin, Rani, \& Alicia, 2020) dimana ciri pegawai yang merasa puas yakni: (1) Pegawai yang bertanggung jawab dan menghargai pekerjaannya akan selalu datang sesuai dengan waktu yang telah ditetapkan ke tempat kerja (2) Saat melakukan pekerjaannya pegawai merasa senang (3) Tidak mengeluh dengan tugas yang dibebankan kepadanya (4) Pegawai semangat dalam melaksanakan pekerjaannya (5) Pegawai betah berada di tempat kerjanya (6) Memiliki hubungan yang baik dengan atasan maupun pegawai lainnya (7) Belajar menjadi lebih baik berkenaan dengan pekerjaannya.

Apabila permasalahan di atas dibiarkan dan tidak mendapatkan perhatian maka tentu saja bisa menjadi penghambat tercapainya tujuan organisasi. Menurut Milvi Tepp, Profesor Organisasi dan Manajemen di Universitas Teknologi Tallinn mengatakan bahwa teknologi yang lebih baik hanya dapat meningkatkan produktivitas organisasi hingga 1/3 tingkat, tetapi lebih dari itu, bahkan 2/3 kinerja yang lebih baik berasal dari pembagian kerja yang baik (Tepp dalam (Kont \& Jantson, 2013)).

\section{Kajian Literatur \\ Pembagian Kerja}

Pembagian kerja didefinisikan sebagai perincian tugas pekerjaan supaya tiap individu dalam organisasi bisa bertanggung jawab untuk melaksanakan sekumpulan kegiatan terbatas (Hastyorini, 2019). Menurut Sondang P. Siagian dalam (Feryanto, Setia, \& Harjaningrum, 2018) ada tiga alasan mengapa perlu dilakukan pembagian kerja yakni:

1. Adanya beban kerja yang harus diselesaikan.

2. Pekerjaan memiliki jenis yang bervariasi.

3. Spesialisasi yang diperlukan beragam.

Menurut A. S. Moenir dalam (Feryanto, Setia, \& Harjaningrum, 2018) manfaat pembagian kerja sebagai berikut: 
1. Memberikan kemudahan bagi pekerja dalam melaksanakan pekerjaannya tanpa harus menunggu perintah.

2. Dapat mengetahui secara jelas perihal wewenang serta tanggung jawab atas tugas yang diberikan.

3. Tidak membuat ragu saat melaksanakan pekerjaan.

4. Memudahkan dalam hal pengawasan pelaksanaan pekerjaan.

5. Tidak terjadi benturan saat melaksanakan tugas.

6. Dasar pertimbangan dalam penetapan kebutuhan akan pendidikan

Dimensi yang digunakan untuk mengukur pembagian kerja sebagai berikut (Hastyorini, 2019):

1. Penempatan karyawan atau pekerja

Penempatan karyawan menggambarkan bahwa karyawan ditempatkan sesuai keahlian atau kompetensi yang dimiliki. Pelaksanaan pekerjaan bisa menjadi tidak maksimal diakibatkan ketidaktepatan dalam menempatkan karyawan.

2. Beban kerja

Beban kerja berkaitan dengan tugas yang diamanahkan untuk dilaksanakan oleh orang tertentu. Beban kerja harus dibagi secara adil (merata) kepada karyawan. Dengan demikian, tidak akan terjadi penumpukan beban kerja pada karyawan tertentu, sementara karyawan lainnya memiliki beban kerja sedikit.

3. Spesialisasi pekerjaan

Spesialisasi dilakukan berdasarkan keahlian atau keterampilan khusus. Spesialisasi pekerjaan diperlukan karena setiap orang tidak memiliki keahlian yang sama. Oleh karena itu, agar setiap pekerjaan dapat dilaksanakan dengan baik diperlukan spesialisasi pekerjaan. Spesialisasi menciptakan efisiensi dalam pelaksanaan pekerjaan yang menjadi tanggung jawab setiap karyawan.

\section{Kepuasan Kerja}

Kepuasan kerja didefinisikan sebagai perasaan yang dimiliki seorang pekerja mengenai pekerjaannya. (Smith, Kendall, dan Hulin dalam (Castanheira, 2014)). Lebih lanjut Robbins dalam (Busro, 2018) mengungkapkan bahwa kepuasan kerja ialah hasil evaluasi dari beberapa karakteristik yang menghasilkan perasaan positif. Dapat diartikan positif apabila hasil yang didapatkan lebih banyak daripada yang diharapkan.

Spector dalam (Adeyoyin, Unazi, Oyewunmi, Adegun, \& Ayodele, 2015) mengungkapkan bahwa kepuasan kerja sangat membantu dalam mengevaluasi kesehatan emosional dan kebugaran mental karyawan. Secara signifikan, kepuasan kerja sangat penting untuk pertumbuhan karyawan yang berkelanjutan di samping pengetahuan, keterampilan, kompetensi, serta strategi profesional, dalam menentukan keberhasilan dan kinerja organisasi.

Faktor yang dapat memengaruhi kepuasan kerja individu yaitu (Herzberg dalam (Busro, 2018)):

1. Faktor Psikologi, berkaitan dengan kondisi psikis karyawan, diantaranya minat, sikap terhadap kerja, ketentraman saat bekerja, serta talenta dan skill.

2. Faktor Sosial, berkaitan dengan hubungan sosial, diantaranya hubungan sesama pegawai, atasan, atau pegawai lain yang jenis pekerjaannya berbeda.

3. Faktor Fisik, berkaitan dengan keadaan lingkungan kerja serta pegawai, diantaranya kelengkapan fasilitas penunjang kerja, jenis pekerjaan, lingkungan kerja, kondisi pegawai, dan jenis pekerjaan.

4. Faktor Finansial, berkaitan dengan kesejahteraan karyawan yang dijamin oleh perusahaan, diantaranya jaminan sosial, tunjangan serta fasilitas yang disediakan, promosi, serta sistem serta besaran gaji.

Ada lima dimensi yang menggambarkan karakteristik yang paling penting dari sebuah pekerjaan.

Dimensi tersebut terdiri dari (Smith, Kendall, dan Hulin dalam (Noermijati, 2013)):

1. Pekerjaan itu sendiri

Sejauh mana pekerjaan dapat memberi seseorang tugas atau pekerjaan yang menyenangkan, peluang untuk belajar, dan kesempatan untuk menerima tanggung jawab.

2. Gaji

Jumlah upah finansial yang diterima sesuai dengan beban kerja dan sejauh mana upah ini dipandang adil dibandingkan dengan apa yang telah diterima oleh karyawan lain dalam organisasi.

3. Promosi 
Adanya peluang yang sama bagi karyawan untuk mendapatkan jabatan yang lebih tinggi dalam suatu organisasi berdasarkan kemampuan atau senioritas.

4. Penyeliaan atau supervisi

Hal ini berkaitan dengan kemampuan atasan untuk menciptakan perasaan nyaman bagi bawahannya saat melakukan pekerjaan dengan pemberian dukungan serta bantuan teknis.

5. Rekan kerja (coworker)

Berkaitan dengan rekan kerja yang dapat memberikan dukungan serta cakap secara teknis, rekan kerja memiliki peranan yang penting dikarenakan untuk mencapai kepuasan harus ada kekompakan dalam kelompok kerja.

\section{Pengaruh Pembagian Kerja Terhadap Kepuasan Kerja}

Pembagian kerja yang baik merupakan kunci utama bagi pelaksanaan pekerjaan namun sebaliknya apabila pembagian kerja dilakukan dengan ceroboh, akan menimbulkan kegagalan dalam pekerjaan (Feryanto, Setia, \& Harjaningrum, 2018). Dengan adanya pembagian kerja, pelaksanaan pekerjaan pun bisa menjadi lebih optimal dan membuat pegawai merasa puas sehingga akan berdampak baik pada kinerja pegawai dan tujuan organisasi pun bisa terlaksana.

Menurut Smith, Kendall, dan Hulin dalam (Castanheira, 2014) kepuasan kerja didefinisikan sebagai perasaan yang dimiliki seorang pekerja mengenai pekerjaannya. Lebih jauh Robbins dalam (Busro, 2018) mengungkapkan bahwa kepuasan kerja ialah hasil evaluasi dari beberapa karakteristik yang menghasilkan perasaan positif, dikatakan positif apabila hasil yang didapatkan lebih banyak daripada yang diharapkan. Faktor yang dapat memengaruhi kepuasan kerja diantaranya sikap terhadap kerja, lingkungan pekerjaan, jenis pekerjaan, minat dan skill (Herzberg dalam (Busro, 2018)). Di mana faktor-faktor tersebut termuat dalam dimensi pembagian kerja.

Berdasarkan uraian teori mengenai hubungan pembagian kerja dengan kepuasan kerja maka diperoleh kesimpulan adanya pengaruh antara pembagian kerja terhadap kepuasan kerja. Kepuasan kerja dipengaruhi jenis pekerjaan yang diemban oleh pegawai. Kepuasan kerja dapat meningkat apabila jenis pekerjaan yang dilakukan oleh pegawai sesuai dengan apa yang didapat atau diharapkan. Dengan kata lain, kepuasan kerja menjadi salah satu parameter keberhasilan perusahaan dalam melakukan pembagian kerja.

\begin{tabular}{||l|l|}
\hline Pembagian Kerja & \multicolumn{1}{|c|}{ Kepuasan Kerja } \\
1. Penempatan & 1. Pekerjaan itu sendiri \\
karyawan atau & pekerja \\
2. Beban kerja & 2. Gaji \\
3. Spesialisasi & 3. Peluang promosi \\
pekerjaan & 4. Penyeliaan/supervisi \\
(Hastyorini, 2019) & 5. Rekan kerja \\
& (Smith, Kendall, dan Hulin \\
dalam (Noermijati, 2013))
\end{tabular}

\section{Gambar 1 Kerangka Pemikiran}

Berdasarkan gambar 1, dapat diketahui hipotesis dalam penelitian ini yaitu:

Ho: Tidak ada pengaruh pembagian kerja terhadap kepuasan kerja pada pegawai di Perum DAMRI Bandung.

Ha: Ada pengaruh pembagian kerja terhadap kepuasan kerja pada pegawai di Perum DAMRI Bandung. 


\section{Metode Penelitian}

Penelitian ini menggunakan pendekatan kuantitatif eksplanatori dengan tujuan untuk menggambarkan mengapa suatu peristiwa terjadi dan apa yang menjadi sebabnya (Gursida \& Harmon, 2017). Diolah menggunakan perangkat lunak IBM SPSS Statistik 24. Penelitan ini dilakukan terhadap pegawai kantor Perum DAMRI Bandung sebanyak 101 orang menggunakan teknik non-probability sampling dengan jenis sampel jenuh. Kuesioner yang disebar menggunaan skala likert's dengan rentang 1-5.

\section{Hasil dan Pembahasan}

\section{Profil Responden}

Tabel 1 merupakan data responden yang mengisi kuesioner penelitian dengan jumlah 101 responden.

Tabel 1 Profil Responden

\begin{tabular}{|c|c|c|}
\hline Karakteristik & $\begin{array}{c}\text { Jumlah Responden } \\
\text { (orang) }\end{array}$ & Persentase \\
\hline $\begin{array}{l}\text { Jenis Kelamin: } \\
\text { 1. Laki-Laki } \\
\text { 2. Perempuan }\end{array}$ & $\begin{array}{c}96 \\
5\end{array}$ & $\begin{array}{l}95 \% \\
5 \%\end{array}$ \\
\hline $\begin{array}{l}\text { Usia: } \\
\text { 1. } 18-25 \text { Tahun } \\
\text { 2. } 26-35 \text { Tahun } \\
\text { 3. } 36-45 \text { Tahun } \\
\text { 4. } 46-55 \text { Tahun } \\
\text { 4. > 55 Tahun }\end{array}$ & $\begin{array}{c}8 \\
12 \\
22 \\
55 \\
4\end{array}$ & $\begin{array}{c}7,9 \% \\
11,9 \% \\
21,8 \% \\
54,5 \% \\
4 \%\end{array}$ \\
\hline $\begin{array}{l}\text { Jabatan: } \\
\text { 1. Manajer } \\
\text { 2. Asisten Manajer } \\
\text { 3. Staff }\end{array}$ & $\begin{array}{c}3 \\
9 \\
89\end{array}$ & $\begin{array}{c}3 \% \\
8,9 \% \\
88,1 \%\end{array}$ \\
\hline $\begin{array}{l}\text { Sub Divisi: } \\
\text { 1. Manajer Keuangan, SDM, Umum } \\
\text { 2. SDM } \\
\text { 3. Pemasaran dan Pengembangan Usaha } \\
\text { 4. Keuangan } \\
\text { 5. Umum } \\
\text { 6. Perencanaan Pelayanan Jasa } \\
\text { 7. Pengendalian Operasi Jasa } \\
\text { 8. ManajerTeknik } \\
\text { 9. Perencanaan dan Rekayasa Teknik } \\
\text { 10. Teknik Perawatan } \\
\text { 11. Teknik Perbaikan }\end{array}$ & $\begin{array}{c}1 \\
5 \\
13 \\
13 \\
5 \\
13 \\
2 \\
1 \\
12 \\
19 \\
17 \\
\end{array}$ & $\begin{array}{c}1 \% \\
5 \% \\
12,9 \% \\
12,9 \% \\
5 \% \\
12,9 \% \\
2 \% \\
1 \% \\
11,9 \% \\
18,8 \% \\
16,8 \% \\
\end{array}$ \\
\hline $\begin{array}{l}\text { Pendidikan: } \\
\text { 1. SMP } \\
\text { 2. SMA/K/Sederajat } \\
\text { 3. D1 } \\
\text { 4. D2 } \\
\text { 5. D3 } \\
\text { 6. D4/S1 } \\
\text { 7. S2 } \\
\end{array}$ & $\begin{array}{c}2 \\
72 \\
1 \\
1 \\
6 \\
17 \\
1\end{array}$ & $\begin{array}{c}2 \% \\
72,3 \% \\
1 \% \\
1 \% \\
5,9 \% \\
16,8 \% \\
1 \% \\
\end{array}$ \\
\hline $\begin{array}{l}\text { Periode Bekerja: } \\
\text { 1. } 1-3 \text { Tahun } \\
\text { 2. } 3,1-6 \text { Tahun }\end{array}$ & $\begin{array}{l}9 \\
7\end{array}$ & $\begin{array}{l}8,9 \% \\
6,9 \%\end{array}$ \\
\hline
\end{tabular}




\begin{tabular}{|l|c|c|}
\hline \multicolumn{1}{|c|}{ Karakteristik } & $\begin{array}{c}\text { Jumlah Responden } \\
\text { (orang) }\end{array}$ & Persentase \\
\hline 3. 6,1 - 9 Tahun & 8 & $7,9 \%$ \\
4. 9,1 - 12 Tahun & 1 & $1 \%$ \\
5. > 12 Tahun & 76 & $75,2 \%$ \\
\hline Pendapatan Per Bulan: & 1 & $1 \%$ \\
1. Rp 1.000.000 - Rp 2.000.000 & 16 & $15,8 \%$ \\
2. Rp 2.000.001 - Rp 3.000.000 & 75 & $74,3 \%$ \\
3. Rp 3.000.001 - Rp 5.000.000 & 9 & $8,9 \%$ \\
4. > Rp 5.000.001 & & \\
\hline
\end{tabular}

\section{Uji Validitas dan Reabilitas}

Uji validitas dan reabilitas dilakukan pada 30 responden dengan metode korelasi Pearson. Hasil pengujian pada variabel pembagian kerja dan kepuasan kerja menghasilkan nilai $r$ hitung $>0.3610$ dengan demikian semua instrumen pada setiap item dinyatakan valid (Herlina, 2019). Uji reabilitas dilakukan pada 30 responden dengan metode Cronbach's Alpha. Hasil pengujian pada variabel pembagian kerja yaitu 0.872 dan pada variabel kepuasan kerja yaitu 0.903 . Reabilitas dinyatakan baik apabila nilai Cronbach's Alpha > 0.8 (Herlina, 2019).

\section{Uji Asumsi Dasar}

Nilai signifikansi dalam uji normalitas yakni 0.200 nilai tersebut di atas 0.05 sehingga dapat disimpulkan dari uji Kolmogorov Smirnov ini data yang diolah memiliki distribusi yang normal. Nilai signifikansi (Sig. Deviation from Linearity) lebih besar dari 0,05 maka dapat dikatakan bahwa kedua variabel adalah linear. Hasil dari uji heteroksidasitas nilai sig. (2-tailed) sebesar $0.681>$ lebih besar daripada 0,05 . Hal ini berarti data sudah baik karena tidak mengalami gejala heteroskedasitas.

\section{Analisis Korelasi}

Nilai signifikansi dalam uji analisis korelasi sebesar 0,000. Ini berarti nilai 0,000 $<0,05$ sehingga dapat dinyatakan terdapat hubungan (korelasi) antara dua variabel. Selain itu, nilai dari pearson correlation yakni 0,494 yang berarti tingkat korelasi antara pembagian kerja dengan kepuasan kerja termasuk ke dalam derajat hubungan korelasi sedang dan berhubungan secara positif.

\section{Analisis Regresi Sederhana}

Rumus regresi yang didapat dari hasil pengujian adalah:

$$
\mathrm{Y}=36,064+0,494 \mathrm{X}
$$

Konstanta sebesar 36,064 mengandung arti apabila variabel pembagian kerja dianggap sama dengan nol maka nilai variabel kepuasan kerja adalah sebesar 36,064. Koefisien regresi X sebesar 0,494 menyatakan bahwa setiap penambahan $1 \%$ atau satu poin nilai pembagian kerja, maka nilai kepuasan kerja bertambah sebesar 0,494. Koefisien regresi tersebut bernilai positif, sehingga dapat dikatakan bahwa arah pengaruh variabel $\mathrm{X}$ terhadap $\mathrm{Y}$ adalah positif.

\section{Analisis Koefisien Determinasi}

Besarnya nilai korelasi atau hubungan $(\mathrm{R})$ yaitu sebesar 0,494. Dari output tersebut diperoleh koefisien determinasi ( $\mathrm{R}$ square) sebesar 0,244 yang berarti pengaruh variabel bebas (pembagian kerja) terhadap variabel terikat (kepuasan kerja) adalah sebesar 24,4\%. Sedangkan untuk sisanya 75,6\% (100\% - 24,4\% $=75,6 \%$ ) merupakan variabel lain yang dapat memiliki pengaruh terhadap variabel kepuasan kerja.

\section{Uji Hipotesis}

Diketahui bahwa nilai t hitung sebesar 5.651 > t tabel 1,984 maka Ho ditolak. Sehingga dapat disimpulkan bahwa variabel pembagian kerja berpengaruh terhadap kepuasan kerja pada pegawai di Perum DAMRI Bandung. Nilai signifikansi sebesar 0,000 < 0,05 sehingga dapat disimpulkan bahwa variabel pembagian kerja $(\mathrm{X})$ berpengaruh signifikan terhadap variabel kepuasan kerja (Y) pada pegawai di Perum DAMRI Bandung. 


\section{Analisis Deskriptif}

Dari tabel 2 nilai rata-rata yang diperoleh untuk variabel pembagian kerja ialah 3.1. Menurut skala interval nilai tersebut termasuk ke dalam kategori "cukup". Selain itu, mean dari tiap dimensi seperti penempatan karyawan, beban kerja, dan spesialisasi kerja termasuk ke dalam kategori "cukup". Sehingga dapat disimpulkan bahwa variabel pembagian kerja di Perum DAMRI Bandung dinyatakan cukup.

Tabel 2 Hasil Analisis Deskriptif Pembagian Kerja

\begin{tabular}{|c|c|c|c|c|c|}
\hline \multicolumn{6}{|c|}{ Pembagian Kerja } \\
\hline Dimensi & Indikator & Min & Maks & Mean & $\begin{array}{l}\text { Mean per } \\
\text { Dimensi }\end{array}$ \\
\hline \multirow{3}{*}{$\begin{array}{l}\text { Penempatan } \\
\text { Karyawan }\end{array}$} & Penempatan sesuai dengan minat. & 1 & 5 & 3.58 & \multirow{3}{*}{3.29} \\
\hline & $\begin{array}{l}\text { Penempatan sesuai dengan latar } \\
\text { belakang pendidikan. }\end{array}$ & 1 & 5 & 2.91 & \\
\hline & $\begin{array}{l}\text { Penempatan sesuai dengan } \\
\text { keterampilan. }\end{array}$ & 2 & 5 & 3.38 & \\
\hline \multirow{3}{*}{ Beban Kerja } & $\begin{array}{l}\text { Beban kerja didistribusikan secara } \\
\text { merata. }\end{array}$ & 2 & 5 & 2.61 & \multirow{3}{*}{2.82} \\
\hline & Deksripsi pekerjaan jelas. & 2 & 5 & 3.36 & \\
\hline & $\begin{array}{ll}\text { Kesesuaian deksripsi } & \text { pekerjaan } \\
\text { dengan tugas sebenarnya. } & \\
\end{array}$ & 2 & 5 & 2.51 & \\
\hline \multirow{3}{*}{ Spesialisasi Kerja } & $\begin{array}{l}\text { Kesesuaian dengan latar belakang } \\
\text { pendidikan yang telah dijalani. }\end{array}$ & 1 & 5 & 2.91 & \multirow{3}{*}{3.23} \\
\hline & $\begin{array}{l}\text { Kesesuaian dengan keahlian yang } \\
\text { dimiliki. }\end{array}$ & 2 & 5 & 3.47 & \\
\hline & $\begin{array}{l}\text { Kesesuaian dengan pelatihan yang } \\
\text { telah dijalani. }\end{array}$ & 2 & 5 & 3.33 & \\
\hline \multicolumn{2}{|r|}{ Rata-rata } & \multicolumn{4}{|c|}{3.1} \\
\hline
\end{tabular}

Tabel 3 Hasil Analisis Deskriptif Kepuasan Kerja

\begin{tabular}{|c|c|c|c|c|c|}
\hline \multicolumn{6}{|c|}{ Kepuasan Kerja } \\
\hline Dimensi & Indikator & Min & Maks & Mean & $\begin{array}{c}\text { Mean } \\
\text { per } \\
\text { Dimensi }\end{array}$ \\
\hline \multirow{3}{*}{ Pekerjaan itu Sendiri } & $\begin{array}{l}\text { Penguasan keahlian berkenaan dengan } \\
\text { pekerjaan. }\end{array}$ & 2 & 5 & 3.50 & \multirow{3}{*}{3.44} \\
\hline & Peluang menggunakan ide. & 2 & 5 & 3.88 & \\
\hline & Kenyamanan kondisi tempat kerja. & 1 & 5 & 2.95 & \\
\hline \multirow{3}{*}{ Gaji } & Kesesuaian gaji dengan beban kerja & 1 & 5 & 3.09 & \multirow{3}{*}{3.21} \\
\hline & Gaji mencukupi kebutuhan sehari-hari & 1 & 5 & 3.08 & \\
\hline & $\begin{array}{l}\text { Pemberian remunerasi kepada } \\
\text { pegawai dengan performa baik. }\end{array}$ & 1 & 5 & 3.47 & \\
\hline \multirow{4}{*}{ Promosi } & $\begin{array}{l}\text { Peraturan yang jelas mengenai } \\
\text { promosi jabatan. }\end{array}$ & 1 & 5 & 3.41 & \multirow{4}{*}{3.25} \\
\hline & $\begin{array}{l}\text { Sosialisasi mengenai kebijakan } \\
\text { promosi. }\end{array}$ & 1 & 5 & 2.81 & \\
\hline & $\begin{array}{l}\text { Promosi diberikan kepada karyawan } \\
\text { yang memiliki performa baik. }\end{array}$ & 1 & 5 & 3.32 & \\
\hline & Kesempatan promosi merata. & 1 & 5 & 3.48 & \\
\hline Supervisi/Penyeliaan & $\begin{array}{l}\text { Pimpinan menampung aspirasi dan } \\
\text { keluhan. }\end{array}$ & 1 & 5 & 3.71 & 3.60 \\
\hline
\end{tabular}




\begin{tabular}{|l|l|c|c|c|c|}
\hline \multirow{4}{*}{ Rekan Kerja } & Pengarahan kerja yang jelas. & 2 & 5 & 3.51 & \\
\cline { 2 - 5 } & Dukungan yang diberikan pimpinan. & 1 & 5 & 3.60 & \\
\hline & Membantu saat kesulitan. & 1 & 5 & 3.82 & \multirow{3}{*}{3.97} \\
\cline { 2 - 5 } & Kenyamanan. & 3 & 5 & 4.06 \\
\cline { 2 - 5 } & Kedekatan. & 3 & 5 & 4.11 & \\
\cline { 2 - 4 } & $\begin{array}{l}\text { Dapat dipercaya dan diajak bekerja } \\
\text { sama. }\end{array}$ & 3 & 5 & 3.91 & \\
\hline \multicolumn{2}{|l|}{ Rata-rata } & \multicolumn{3}{|c|}{3.5} \\
\hline
\end{tabular}

Dari tabel 3 nilai rata-rata yang diperoleh untuk variabel kepuasan kerja ialah 3.5. Menurut skala interval nilai tersebut termasuk ke dalam kategori "baik". Selain itu, mean dari dimensi pekerjaan itu sendiri, supervisi/penyeliaan, dan rekan kerja termasuk ke dalam kategori "baik". Namun, untuk dimensi gaji serta promosi termasuk ke dalam kategori "cukup". Sehingga untuk keseluruhan disimpulkan bahwa kepuasan kerja di Perum DAMRI Bandung dinyatakan sudah baik.

\section{Pembahasan}

Berdasarkan hasil analisis deksriptif, variabel pembagian kerja termasuk ke dalam kategori cukup. Pada dimensi penempatan karyawan masih banyak responden yang belum ditempatkan sesuai dengan minat, keterampilan, serta latar belakang pendidikan yang dijalani. Padahal menurut Werther \& Davis dalam (Agustriyana, 2015) salah satu faktor latar belakang pendidikan yang telah dijalani sebelumnya harus dijadikan bahan pertimbangan dalam penempatan karyawan. Penempatan dengan baik dan tepat merupakan bentuk pengoptimalan sumber daya manusia yang dimiliki oleh perusahaan, ketidaktepatan dalam menempatkan karyawan akan menyebabkan pelaksanaan pekerjaan menjadi kurang optimal. Dengan penempatan yang tepat pula akan menyebabkan pegawai merasa tertarik, senang, dan puas sehingga penempatan dapat meningkatkan kepuasan kerja.

Pada dimensi beban kerja, deksripsi pekerjaan juga belum terdeksripsi dengan jelas, padahal supervisor dan kepala divisi menggunakan deskripsi pekerjaan sebagai dasar untuk menetapkan pekerjaan dan memperjelas ekspektasi kinerja. Deskripsi pekerjaan juga merupakan alat utama dalam penilaian kinerja, di mana supervisor mengevaluasi kinerja pekerjaan pemegang jabatan (The Blackwell Encyclopedic Dictionary of Human Resource Management dalam (Kont \& Jantson, 2013)). Selain itu, pegawai juga sering mengerjakan tugas yang tidak ada pada deksripsi pekerjaan mereka, padahal menurut Manullang dalam (Arfiany, 2019) pembagian tugas merupakan penunjukkan tugas atau kewajiban kepada orang lain untuk meringankan beban pekerjaan seseorang. Pihak manajemen perlu menganalisis ulang beban kerja dan mendistribusikannya secara merata serta menumbuhkan kesadaran akan peran masing-masing juga dapat menjadi kunci supaya pegawai dapat mengerjakan tugas sesuai dengan porsinya masing-masing.

Pada bagian spesialisasi pekerjaan banyak responden yang menilai bahwa pendidikan dan pelatihan yang telah dijalani belum sesuai dengan pekerjaan saat ini. Padahal pendidikan dan pelatihan merupakan sarana yang dapat dimanfaatkan oleh individu untuk mengembangkan diri dan memunculkan potensi diri yang mungkin masih terpendam untuk dapat dimaksimalkan menjadi sebuah kekuatan besar. Pentingnya pelatihan juga untuk perbaikan efisiensi kerja karyawan atau meliputi pemahaman pengetahuan serta keterampilan yang mendukung, dan pembentukan sikap yang diinginkan oleh perusahaan (Saleh, 2016).

Berdasarkan hasil analisis deksriptif, variabel kepuasan kerja termasuk ke dalam kategori baik. Kenyamanan kondisi lingkungan tempat bekerja masih dinilai kurang memadai, Lingkungan kerja yang mendukung dan dapat memberi rasa aman dapat membuat pegawai bekerja secara maksimal. Apabila pegawai menyukai lingkungan kerjanya, maka pegawai tersebut akan betah di tempat kerjanya, lalu memanfaatkan waktu secara efektif untuk melakukan aktivitasnya (Afandi, 2016).

Pemberian gaji kepada pegawai harus disesuaikan dengan ketentuan dan peraturan yang berlaku untuk menghindari pelanggaran. Pemberian remunerasi kepada pegawai yang memiliki performa bagus juga bisa menjadi ajang perlombaan bagi pegawai untuk memberikan performa terbaiknya bagi perusahaan dan ini merupakan hubungan timbal balik yang baik. Pemberian remunerasi juga harus disesuaikan dengan kemampuan perusahaan. 
Promosi dapat menjadi alat motivasi bagi pegawai untuk meningkatkan prestasinya. Dengan pemberian kesempatan promosi secara merata kepada seluruh pegawai dapat membuat pegawai lebih semangat untuk bekerja, berdisiplin tinggi, dan meningkatkan kinerjanya. Hal ini juga bisa menimbulkan kepuasan dan kebanggan pribadi (Afandi, 2016).

Pada bagian supervisi/penyeliaan pimpinan dirasa sudah mampu menampung aspirasi dan keluhan para pegawai dan memberikan dukungan serta perhatian saat bekerja. Dukungan yang positif dari atasan dapat menciptakan situasi dan kondisi kerja yang lebih baik (Gorda, 2004). Selain itu, komunikasi yang baik dan pemberian instruksi pelaksaan kerja yang jelas sangat diperlukan untuk menghindari kesalahpahaman pengerjaan tugas. Apabila pihak internal dalam perusahaan mempunyai kerja sama yang baik serta mengutamakan kepentingan bersama hal ini bisa menciptakan iklim kerja yang kondusif sehingga kinerja perusahaan akan menjadi lebih baik (Munthe \& Tiorida, 2017).

Sebagian besar pegawai setuju bahwa rekan kerja akan mencoba membantu untuk mengatasi masalah pekerjaan, merasakan nyaman saat bekerja, dekat, dan percaya bahwa rekan kerja dapat bekerja sama dengan baik. Seperti yang dipaparkan oleh Simamora dalam (Wiyono \& Haryadi, 2014) hubungan rekan kerja yang kuat dapat melahirkan suasana kerja yang baik, saling tolong menolong, saling bekerja sama, menghargai, memberikan dorongan, semangat, dan bertukar informasi berkenaan dengan pekerjaan. Apabila hal tersebut terus ditingkatkan maka pegawai pun bisa merasa puas dan nyaman dengan rekan kerja di perusahaan.

Nilai thitung yang didapat dari hasil penelitian yakni sebesar 5.651 >t tabel 1,984 maka Ho ditolak sehingga bisa diambil kesimpulan bahwa variabel pembagian kerja berpengaruh terhadap kepuasan kerja pegawai Perum DAMRI Bandung. Kemudian berdasarkan hasil signifikansi pada tabel 4.16 didapatkan nilai signifikansi sebesar 0,000 $<0,05$ sehingga bisa diambil kesimpulan bahwa variabel pembagian kerja $(\mathrm{X})$ berpengaruh signifikan terhadap variabel kepuasan kerja $(\mathrm{Y})$ pegawai Perum DAMRI Bandung.

Hasil dari koefisien regresi X sebesar 0,494 menyatakan bahwa setiap penambahan $1 \%$ atau satu poin nilai pembagian kerja, maka nilai kepuasan kerja bertambah sebesar 0,494. Koefisien regresi tersebut bernilai positif, sehingga dapat dikatakan bahwa arah pengaruh variabel $\mathrm{X}$ terhadap $\mathrm{Y}$ adalah positif dan berdasarkan tabel 4.15 besarnya nilai korelasi atau hubungan $(R)$ yaitu sebesar 0,494 . Dari output tersebut diperoleh koefisien determinasi (R square) sebesar 0,244 yang berarti pengaruh variabel bebas (pembagian kerja) terhadap variabel terikat (kepuasan kerja) adalah sebesar $24,4 \%$. Sedangkan untuk sisanya $75,6 \%(100 \%-24,4 \%=75,6 \%)$ merupakan variabel lain yang bisa memiliki pengaruh terhadap variabel kepuasan kerja. Sehingga kesimpulannya pembagian kerja terhadap kepuasan kerja pegawai pada Perum DAMRI Bandung berpengaruh secara signifikan sebesar 24,4\%.

Meskipun pembagian kerja berada pada kategori cukup namun ternyata kepuasan kerja berada pada kategori baik, hal ini bisa terjadi karena pada hasil penelitian ditemukan bahwa elemen kepuasan tertinggi dicapai oleh dimensi supervisi/penyeliaan dengan mean 3,60 dan dimensi rekan kerja dengan mean 3,96. Ini mengindikasikan bahwa dukungan sosial dari atasan dan sesama rekan kerja memengaruhi kepuasan kerja cukup besar, dukungan yang positif dari atasan dapat menciptakan situasi dan kondisi kerja yang lebih baik serta hubungan rekan kerja yang kuat dapat melahirkan suasana kerja yang baik, saling tolong menolong, saling bekerja sama, menghargai, memberikan dorongan, semangat, dan bertukar informasi berkenaan dengan pekerjaan. Sehingga pegawai pun merasa puas dan nyaman baik dengan rekan kerja maupun atasan di perusahaan.

\section{Kesimpulan}

Pembagian kerja pada Perum DAMRI Bandung sudah dapat dinyatakan cukup. Dilihat pada dimensi penempatan, beban kerja, serta spesialisasi kerja yang memiliki mean cukup. Kepuasan kerja pada Perum DAMRI Bandung sudah dapat dinyatakan baik. Meskipun kepuasan kerja berada dalam kategori baik, akan tetapi pada dimensi gaji dan promosi memiliki mean cukup. Pembagian kerja berpengaruh secara signifikan dan positif terhadap kepuasan kerja Perum DAMRI Bandung sebesar 24,4\%. 


\section{Daftar Pustaka}

Adeyoyin, S. O., Unazi, F. A., Oyewunmi, O. O., Adegun, A. I., \& Ayodele, R. O. (2015). Effects of Job Specialization and Departmentalization on Job Satisfaction Among the Staff of a Nigerian University Library. Library Philosophy and Practice, 1-20.

Afandi, P. (2016). Concept \& Indicator Human Resources Management for Management Research. Yogyakarta: Deepublish.

Agustriyana, D. (2015). Analisis Faktor-faktor Penempatan Karyawan Terhadap Kepuasan Kerja Karyawan di PT Yuniko Asia Prima di Kota Bandung. Jurnal Ekonomi, Bisnis \& Entrepreneurship, 158-178.

Arfiany. (2019). Pengaruh Pembagian Kerja Terhadap Efektivitas Kerja Karyawan Bagian Produksi PT. Tiga Saudara Indonusa Makassar. SIMAK, 1-18.

Busro, M. (2018). Teori-teori Manajemen Sumber Daya Manusia. Jakarta: Prenadamedia Group.

Castanheira, F. (2014). Job Descriptive Index. In: Michalos A.C. (eds) Encyclopedia of Quality of Life and Well-Being Research. Springer, Dordrecht. doi:https://doi.org/10.1007/978-94-007-07535_1565

Chaerudin, A., Rani, I. H., \& Alicia, V. (2020). Sumber Daya Manusia: Pilar Utama Kegiatan Operasional Organisasi. Kab. Sukabumi: CV Jejak.

DAMRI. (2019). Annual Report DAMRI 2019 Improved Strategy to Reinforce Our Presence Across Archipelago. Jakarta: DAMRI.

Feryanto, A., Setia, H. P., \& Harjaningrum, A. R. (2018). Buku Referensi: Seri Ensiklopedia IPS Materi Ekonomi Volume 3 Spesialisasi dan Pembagian Kerja. Klaten: Cempaka Putih.

Gorda, I. N. (2004). Manajemen Sumber Daya Manusia. Denpasar: Astabrata.

Gursida, H., \& Harmon. (2017). Metode Penelitian Bisnis dan Keuangan Konsep dan Implementasinya. Bogor: PASPI.

Hastyorini, I. R. (2019). Spesialisasi Tenaga Kerja. Klaten: Cempaka Putih.

Herlina, V. (2019). Panduan Praktis Mengolah Data Kuesioner Menggunakan SPSS. Jakarta: PT Elex Media Komputindo.

Kont, K., \& Jantson, S. (2013). Division of Labor and Coordination, Intra-organizational Career and Salary Fairness: Study in Estonian University Libraries. Library Management, 34(6/7), 415432. doi:https://doi.org/10.1108/LM-10-2012-0069

Munthe, K., \& Tiorida, E. (2017). Pengaruh Komunikasi Internal Terhadap Kinerja Karyawan. Jurnal Riset Bisnis dan Investasi, 86-97.

Noermijati. (2013). Kajian Tentang Aktualisasi Teori Herzberg, Kepuasan Kerja dan Kinerja Spiritual Manajer Operasional. Malang: Universitas Brawijaya Press (UB Press).

Saleh, A. M. (2016). Manajemen Training: Teknik Praktis Pengelolaan Training dan Pelatihan Sumber Daya. Malang: Universitas Brawijaya Press.

Wiyono, Y., \& Haryadi, B. (2014). Peran Pemimpin, Rekan Kerja, dan Keluarga dalam Memotivasi Karyawan di PT Mulya Adhi Paramita Surabaya. AGORA, 1-11.

\section{*Email korespondensi:}

pratiwi.abs417@polban.ac.id 